\title{
Evaluation of the inhibition process effect "Preg-robbing" for gold recovery (AU)
}

\author{
Gregorio Urbano Palma Figueroa ${ }^{1}$, Javier Alonso Villegas Aragón ${ }^{1}$, María del Carmen Camiña Pachecoㄹ, \\ Lilia Mary Miranda Ramos ${ }^{1}$, Antonio Erick Linares Flores Castro ${ }^{2}$, Hugo Guillermo Jiménez Pacheco ${ }^{2}$ \\ ${ }^{1}$ Universidad Nacional de San Agustín, Arequipa, Perú. \\ ${ }^{2}$ Universidad Católica de Santa María, Arequipa, Perú
}

\section{INFORMACIÓN}

\section{Historia del Artículo}

Recepción:

Revisión:

Aceptación:

\section{Key Words}

Leaching, thick gold, electrum, gravimetric concentration

\section{DOI}

https://doi.org/10.35286/veritas. v21i1.260

\begin{abstract}
Currently, the National Society of Mining, Petroleum and Energy (SNMPE) states that in recent years the production of gold in Peru has reduced, since in 2016 there was a production of 153 MT, compared to 2005 with a production of 208 MT. Until 2018, a production decrease of $5.4 \%$ was established and in 2017 a decrease of $11.3 \%$. Currently there is a need to develop research on gold extraction processes in low recovery minerals with traditionally used processes, due to the complex structure of gold that prevents their extraction. It is necessary to evaluate new processes that are environmentally friendly and that are sustainable in the environmental and economic aspects. In the present work, the applicability of leaching with $\mathrm{NaCl}$ and $\mathrm{KNO} 3$ in acid medium in a sulphurous gold mineral was evaluated, through the process of leaching with oxidizing salts, which allows to process hydrometallurgy the various forms of gold minerals present in nature. The sample is composed in percentages by Quartz 24\%, Carbonates Dolomite $22 \%$, Calcite $6 \%$, Arsenopyrite $19 \%$, Pyrite $5 \%$, Galena $4 \%$ and clays associated with traces of Native Au-Electrum, which were interfering with the process of leaching of the sample. A pretreatment by gravimetric concentration was carried out using the Falcón equipment, with the aim of releasing the encapsulated gold and eliminating the interfering agents, facilitating the leaching action of the oxidizing salts. When testing the concentrations of the oxidizing salts, it was found that for the concentrations of $86.86 \mathrm{~g} / \mathrm{l}$ of NaCl, $21.96 \mathrm{~g} / \mathrm{l}$ of $\mathrm{KNO} 3$ and $125.93 \mathrm{~g} / \mathrm{l}$ of $\mathrm{H} 2 \mathrm{SO} 4$, a maximum recovery of $26.62 \%$ gold was obtained. Based on the results from the factorial design, an increase in gold extraction performance was observed; obtaining a maximum recovery of $29.31 \%$ of the gold; in the process it was determined that dissolved gold is affected by the presence of clays, producing the "Preg-robbing" effect of the valuable metal and consequently decreasing the recovery of gold after 8 leaching hours. According to the results, it is concluded that the leaching process with oxidizing salts in acidic medium for the type of mineral used, is mainly affected by the presence of coarse gold and electrum associated with clays, establishing conditions of degree of release according to the granulometry in the gold leaching process.
\end{abstract}

\section{INTRODUCTION}

The mining problem currently presents efficiency and performance controversies in environmental aspects and in its processes due to mineral extraction activities. Gold extractive metallurgy has operations that differ from the behavior of competitive reducers in ore re-precipitation (Evelien Martens, 2012), and this item is established as one of the most important sources of wealth within the socioeconomic context of Peru. An operation that is carried out is the Cyanuration, where the leaching of gold in acid medium with oxidizing salts in a low recovery mineral is evaluated, and one of the aspects establishes leaching processes where certain phenomenological models are determined (Edelmira D Gálvez, 2012) and analytical models (Valencia, 2008) (Mellado, 2009), achieving a leaching at different scales of sizes, time and the presence of competitive reducers in the mineral material and the effectiveness of recovery (Martens Evelien, 2012)

Correspondencia:

Hugo G. Jiménez Pacheco

hjimenez@ucsm.edu.pe
According to updated reports from the National Society of Mining, Petroleum and Energy (SNMPE), gold production in Peru in recent years has reduced (SNMPE, 2018) (Misari Chuquipoma, 2010), registering a production of 153 in 2016 TM, compared to 2005 with a production of 208 MT. According to the monthly statistical bulletin of January 2018, there is $5.4 \%$ less production than in January 2017 and $11.3 \%$ less production than in December 2017 (MEN, Dirección de General de Minería, 2017). These figures show the need to develop and promote the investigation of gold extraction processes, specifically in low recovery minerals with traditionally used processes (Cornejo, 2010) (Domic, 2001), due to its complex structure the extraction is avoided of the valuable metal of the gold and copper deposits (Lovera D, 2003) (Meissl Roberto J, 2011) and in the kinetic models and the intrinsic surface reaction of the dissolution of gold respectively (Martens, 2012) (Sipi Seisko, 2018). In addition to evaluating new, more environmentally friendly processes that can be sustainable over time, both environmentally and economically (Severo, 1993), one of the fundamental aspects of gold leaching rates is that they are low to the conditions of sulphurous and oxidized gold ores (Asamoah, 2018), highlighting the mineralogical complexity and its variation to pre-treatments. Within this context, the present investigation established the extraction process using $\mathrm{H} 2 \mathrm{SO} 4$ as a leaching medium and as oxidizing salts $\mathrm{NaCl}$ and $\mathrm{KNO} 3$ in different 
concentrations, to achieve the production of $\mathrm{Cl}$ and royal water, achieving the leaching of valuable mineral.

\section{MATERIALS AND METHODS}

Samples were collected from a mining company, then they were characterized. The samples taken were of 50 $\mathrm{kg}$, a sample quartet of $1 \mathrm{~kg}$ was performed to conduct mineralogical tests and tests to determine the ore grade. Then another quartet was performed for the granulometric analysis with a sample weight of $2.5 \mathrm{~kg}$, sample that went through meshes of different granulometries of 50, 100 and 200 .

\section{Determination of mineralogy}

Mineralogical tests were performed from X-ray Diffraction Analysis, whose composition of the mineral are Pyrite, Pyrrhotite, Arsenopyrite, Chalcopyrite, Sphalerite, Galena and Au Nativo-Electrum.

It was established to perform 3 conditions, in the characterization of the mineral the mechanical preparation of the sample was performed, this was collected from the initial batch of the crushing circuit ore of the plant level, which had a grain size of $1 / 2$ inch, then was subjected to an alternate paleo sampling, then go through a rabbit and quartet obtaining a representative sample of $50 \mathrm{~kg}$.

Luego se realizó el pre tratamiento y el acondicionamiento para llevar a cabo el proceso de lixiviación por agitación con sales oxidantes en medio acido (Jorge, 2012) (Palacios S. , 2002), para ello se pesaron $9 \mathrm{~kg}$ de muestra, la cual luego fue pulverizada a malla número 10 , luego se procedió a usar el equipo Falcon L40-VFD, con una densidad máxima de alimentación del $75 \%$ de sólidos en peso, se usó agua fluidizada típica 1-5 US gpm (4-20 jpm), a una presión de 3 psi, y luego se agregó 21 litros de agua al tanque, se estableció un tiempo de 3 min de agitación para su acondicionado, luego se realizó la descarga del relave, se tomó en cuenta el peso específico de la pulpa y los \% de solidos; para ello se realizó la recirculación del mineral durante $15 \mathrm{~min}$ por dos secuencias consecutivas, luego se establecieron los análisis químico metalúrgico (Taipe Ch., 2015); para la determinación de las leyes del concentrado y relave por vía seca - Fire Assay se procede a los análisis de la solución cargado de oro mediante ensayos de espectrofotometría por absorción atómica.

Then the pretreatment and conditioning was carried out to carry out the leaching process by agitation with oxidizing salts in acidic medium (Jorge, 2012) (Palacios S. , 2002), for this $9 \mathrm{~kg}$ of sample were weighed, then it was sprayed to mesh number 10, then the Falcon L40-VFD equipment was used, with a maximum feed density of $75 \%$ solids by weight, typical 1-5 US gpm (4-20 jpm) and fluidized water was used, at a pressure of 3 psi, and then 21 liters of water was added to the tank, a stirring time of 3 min was established for its conditioning, then the tailings were discharged, the specific weight of the pulp was taken into account and also the \% solids; for this, the recirculation of the mineral was carried out for $15 \mathrm{~min}$ for two consecutive sequences, then the metallurgical chemical analyzes were established (Taipe $\mathrm{Ch}$., 2015); for the determination of the laws of concentrate and dry tailings - Fire Assay, the analysis of the solution loaded with gold is carried out by means of atomic absorption spectrophotometry tests.

\section{Fluidized lixiviation process 1-5 US}

2,934 lt of water are added and then $\mathrm{KNO} 3$ and $\mathrm{NaCl}$ are added to each container, then 500 gr of mineral is added at constant stirring, until there is a dissolution of the salts, the initial $\mathrm{pH}$ is recorded. The samples are monitored every 2 hours, during $24 \mathrm{hrs}$ of recovery, with $30 \mathrm{ml}$ samples for $\mathrm{Au}$ recovery, and then filtered with quantitative filter paper; subsequently they are transferred to test tubes to be analyzed by atomic absorption. See Fig. 1 .

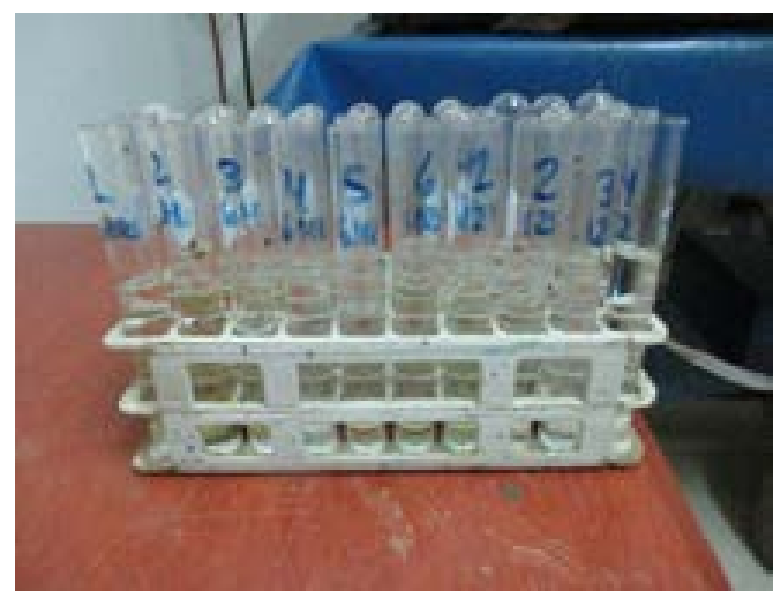

Fig. 1: Acid solutions filtered to be read by atomic absorption.

The gases were established in the Perkin Elmer Analysis 400 atomic absorption gas extractor hood, a 300mm-189$900 \mathrm{~nm}$ focal length spectrophotometer, $2.4 \mathrm{~nm} / \mathrm{mm}$ reciprocal linear dispersion was used; With the characteristics of the activation of the Flame icon with the oxidizing flame, the standardization of the sulfuric acid medium was established, the gold curve was calibrated in acidic medium with the $\mathrm{Ag}$ standards, and once the curve was formed the absorption readings were taken, and then the linearity of the curve was verified with the correlation coefficient greater than 0.999 . See Table 1.

Table 1: Calibration curves for Au, Ag.

\begin{tabular}{cc}
\hline Cond. Au (ppm) & Cond. Ag (pmm) \\
\hline 5 & 10 \\
10 & 20 \\
20 & 50 \\
\hline
\end{tabular}

\section{RESULTS}

Mediante el Análisis de Difractograma se estableció la presencia principal del cuarzo y algunas arcillas asociadas al oro electrum, como las cloritas (Clinocloro), micas (Vermiculita), moscovita (Sericita); se estableció un aumento en la velocidad de dilución del oro con el aumento de la temperatura, encontrándose que la concentración de cloruro relaciona una no dependencia del $\mathrm{pH}$ (Seiko, y otros, 2017). De los resultados obtenidos de análisis ICP óptico se identificaron 38 elementos, observándose que hay mayor porcentaje de: As, S, Fe, Cu, Ag y Zn, sobrepasando el límite de detección (Gallardo, 1980). Ver Figura 2. 
The Difractogram Analysis established the main presence of quartz and some clays associated with electrum gold, such as chlorites (Clinochlor), micas (Vermiculite), Muscovite (Sericite); an increase in the speed of dilution of gold with the increase in temperature was established, finding that the chloride concentration relates a non-dependence on $\mathrm{pH}$ (Seiko, et al., 2017). From the results obtained from optical ICP analysis, 38 elements were identified, observing that there is a higher percentage of: $\mathrm{As}, \mathrm{S}, \mathrm{Fe}, \mathrm{Cu}, \mathrm{Ag}$ and $\mathrm{Zn}$, exceeding the detection limit (Gallardo, 1980). See Fig. 2.

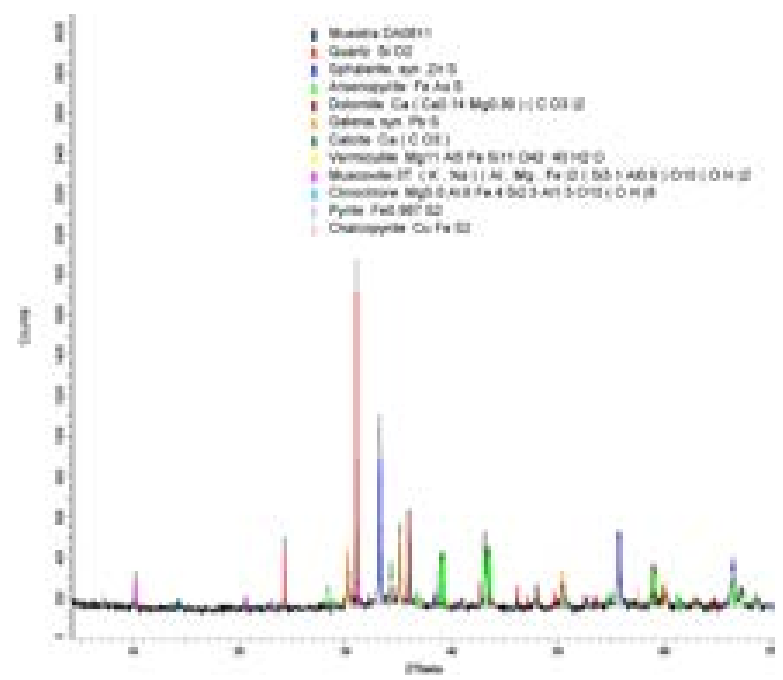

Fig. 2: Diffractogram of Sample DA-0811 showing the minerals identified.

This analysis was performed in a general way for all the mineral compounds, observing a relation of present components.

\section{Mineralog analysis by X-Ray difraction}

An X-ray diffraction was performed on the sample and the results are shown in Table 2.

Table 2: Mineralogical analysis by X-ray diffraction.

\begin{tabular}{ccc}
\hline Mineral Name & Formula & Approximate Result (\%) \\
\hline Quartz & $\mathrm{SiO} 2$ & 24 \\
Carbonates (Dolomite) & $\mathrm{CaMg}(\mathrm{Co} 3) 2$ & 22 \\
Arsenopyrite & $\mathrm{FeAsS}$ & 19 \\
Sphalerite & $(\mathrm{Zn}, \mathrm{Fe}) \mathrm{S}$ & 15 \\
Carbonates (Calcite) & $\mathrm{CaCO} 3$ & 6 \\
Pyrite & $\mathrm{FeS} 2$ & 5 \\
Galena & $\mathrm{PbS}$ & 4 \\
Muscovite (Sericite) & $\mathrm{KAl} 2(\mathrm{Si} 3 \mathrm{Al}) \mathrm{O} 10(\mathrm{OH}, \mathrm{F}) 2$ & 2 \\
Chalcopyrite & $\mathrm{CuFeS} 2$ & 2 \\
Micas (Vermiculite) & $(\mathrm{Mg}, \mathrm{Fe}) 3(\mathrm{Si}, \mathrm{Al}) 4010)$ & $<\mathrm{L} . \mathrm{D}$ \\
Chlorites (Clinochlor) & $(\mathrm{OHg}, \mathrm{Fe}+2, \mathrm{Al}) 6(\mathrm{Si}$, & $<\mathrm{L} . \mathrm{D}$ \\
\hline
\end{tabular}

In the mineralogical analysis, the most relevant are quartz, arsenopyrite, pyrite, muscovite and secondary clays. This corresponds to secondary clay tests $<$ L.D with percentages that are not accurate, so that an analysis is established individually.

\section{Cianuration conditions}

For the tests, the gold sulphide mineral is subjected to a cyanidation test by stirring, showing the percentage of gold recovery in Table 3.

Table 3: Cyanuration conditions

\begin{tabular}{cc}
\hline Description & Value \\
\hline GE of the solid $(\mathrm{kg})$ & 3.077 \\
Sample weight $(\mathrm{Kg})$ & 1.400 \\
Water volume (l) & 3.250 \\
Density (g/t) & 1255 \\
$\%$ Solid & 30.1 \\
Grain size (-200 M) (\%) & 90.00 \\
Total volume (l) & 3.705 \\
NaCN (\%) & 0.500 \\
pH & 12.00 \\
Initial weight of $\mathrm{NaCN}(\mathrm{gr})$ & 16.25 \\
Initial weight of $\mathrm{NaOH}(\mathrm{gr})$ & 5.00 \\
\hline
\end{tabular}

Table 4 shows the samples of the ore head grades, based on these values, the percentage of recovery of Au was determined.

Table 4: Leyes de cabeza de mineral en estudio.

\begin{tabular}{ccc}
\hline Description & $\mathrm{Au}$ & $\mathrm{Ag}$ \\
\hline Head analyzed law (g/TM) & 90.35 & 291.99 \\
Calculated head law (g/TM) & 86.81 & 348.93 \\
Tailings Analyzed Law (g/TM) & 41.31 & 180.32 \\
Total Au Content (g) & 0.1215 & 0.4885 \\
Content of Au in tailings (g) & 0.0578 & 0.2525 \\
\hline
\end{tabular}

Making a comparison, it is observed that the cyanidation time is at 72 hourd for gold extraction, which indicates that the leaching kinetics is very slow for a low recovery percentage. See Fig. 3

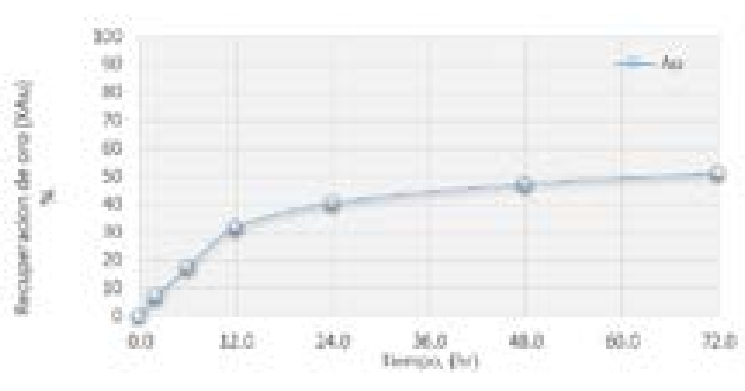

Fig.3: Kinetics of Gold dissolution by Cyanuration. 
Debido a la presencia del oro grueso, se generó una influencia negativa en las pruebas preliminares, perjudicando la recuperación del oro, el oro grueso no puede ser disuelto completamente en la lixiviación; según lo presentado en estudios el marco teórico (Apablaza, Díaz, Rodríguez, \& Vera), donde son procesados con pre tratamiento por medios gravimétricos, en el proceso se aplicó la concentración gravimétrica (Alvarez Q, 2006) (Bustamante R, 1992), y se usó un equipo Falcon, para el análisis por Fire Assay determinando sus leyes de concentrado para granulometría de $90 \% \mathrm{~m}-200$. Ver Tabla 5.

Due to the presence of coarse gold, a negative influence was generated in preliminary tests, damaging the recovery of gold, coarse gold cannot be completely dissolved in leaching; as presented in studies the theoretical framework (Apablaza, Díaz, Rodríguez, \& Vera), where they are processed with pretreatment by gravimetric means, in the process gravimetric concentration was applied (Alvarez Q, 2006) (Bustamante R, 1992), and a Falcon device was used, for the analysis by Fire Assay determining its concentration laws for granulometry of $90 \% \mathrm{~m}-200$. See Table 5 .

Table 5: FALCON concentrate and tailings analysis.

\begin{tabular}{ccccccc}
\hline Components & $\begin{array}{c}\text { Weight, } \\
(\mathrm{gr})\end{array}$ & $\begin{array}{c}\text { Weight, } \\
(\%)\end{array}$ & $\begin{array}{c}\text { Au Law. } \\
(\mathrm{gr} / \mathrm{TM})\end{array}$ & $\begin{array}{c}\text { Ag Law. } \\
(\mathrm{gr} / \mathrm{TM})\end{array}$ & $\begin{array}{c}\text { Ley de } \\
\mathrm{Cu} .\end{array}$ & $\begin{array}{c}\text { Recovery } \\
\% \mathrm{Au}\end{array}$ \\
\hline Head & 9000 & 100.00 & 105.889 & 291.990 & 0.445 & 100 \\
Concentrated & 110 & 1.22 & 2617.404 & 1400.571 & - & 30 \\
Tailings & 8890 & 98.78 & 74.674 & 177.600 & 0.270 & 70 \\
\hline
\end{tabular}

An atomic absorption spectrophotometry analysis was performed at the tailings, observing a law of $74.67 \mathrm{gr} / \mathrm{MT}$ of $\mathrm{Au}$ and $0.270 \%$ of $\mathrm{Ag}$, the recovery efficiency of the $\mathrm{Au}$ was verified, and then it was subjected to the gravimetric pretreatment, applying the traditional process of cyanidation. See Table 6.

Table 6: Cyanidation process to Falcon tailings.

\begin{tabular}{cccccc}
\hline Time & Hour & $\begin{array}{c}\text { Dissolution } \\
\text { Au. }(\mathrm{g} / \mathrm{l})\end{array}$ & $\begin{array}{c}\text { Dissolution } \\
\text { Ag.(g/l) }\end{array}$ & $\begin{array}{c}\text { Recovery } \\
\% \mathrm{Au}\end{array}$ & $\begin{array}{c}\text { Recovery } \\
\% \mathrm{Ag}\end{array}$ \\
\hline T1 & 6 & 6.11 & 16.82 & 19 & 22 \\
T2 & 12 & 10.02 & 22.64 & 31 & 30 \\
T3 & 24 & 14.56 & 30.86 & 45 & 40 \\
T4 & 40 & 16.14 & 37.07 & 50 & 48 \\
T5 & 60 & 16.62 & 43.40 & 52 & 57 \\
T6 & 72 & 17.49 & 45.57 & 54 & 60 \\
\hline
\end{tabular}

The pretreatment effect shows a slight increase in recovery of $54 \% \mathrm{Au}$ and $60 \% \mathrm{Ag}$, since the pre treatment for $52.41 \%$ for $\mathrm{Au}$ and $48.32 \% \mathrm{Ag}$ were obtained.

Then it was verified that the presence of coarse gold and that the main " $\mathrm{Cu}$ minerals" cyanicides are released from the ore, allowing the ore from the tailings to be partially free of coarse Au. This is shown in Fig. 4, you can see the recovery conditions and the optimal time after 8 hours. The graph is the comparison of the trend followed by the four tests of time and the recovery of Au.

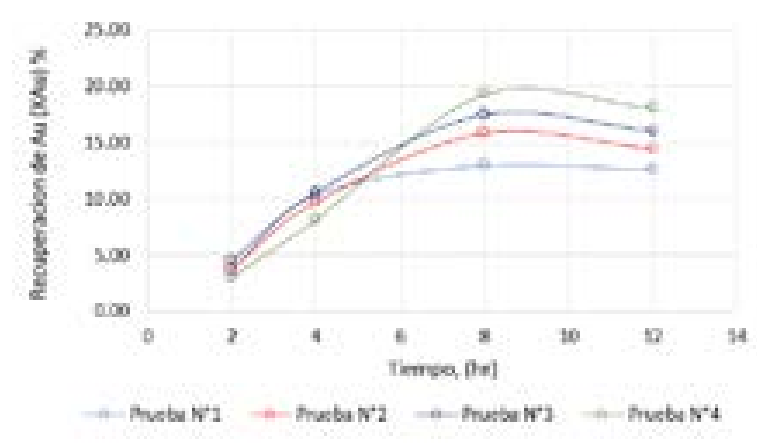

Fig. 4: Influence of time in the recovery of Au.

It is observed that the recovery of $\mathrm{Au}$, is increasing until 8 hours and has a tendency to remain constant until 12 hours, from this hour there is a slight decrease in concentration.

\section{Influence of oxidizing salts}

The determination of the concentrations of $\mathrm{H} 2 \mathrm{SO} 4$, $\mathrm{NaCl}$ and $\mathrm{KNO} 3$ that affect the recovery of $\mathrm{Au}$ from leaching in an acid medium of the mineral from the mining company establish the recovery of Au, established in similar studies (Palacios S. , 2002) whose evaluation at Different concentrations are referred to bibliographic studies (Alfaro Lopez, 2014).

Table 7 shows the highest yield in gold recovery, the concentration of oxidizing salts and $\mathrm{H} 2 \mathrm{SO} 4$ of run 04 .

Table 7: Recovery of Au at different concentrations.

\begin{tabular}{cccccc}
\hline Run & $\begin{array}{c}\mathrm{SO} 4 \mathrm{H} 2 \\
(\mathrm{~g} / \mathrm{l})\end{array}$ & $\mathrm{pH}$ & $\begin{array}{c}\mathrm{ClNa} \\
(\mathrm{g} / \mathrm{l})\end{array}$ & $\begin{array}{c}\mathrm{KNO}_{3} \\
(\mathrm{~g} / \mathrm{l})\end{array}$ & $\begin{array}{c}\text { Recovery } \\
(\% \mathrm{Au})\end{array}$ \\
\hline 1 & 29.06 & 1.3 & 20.02 & 5.17 & 12.9353 \\
2 & 38.75 & 0.9 & 26.80 & 6.78 & 15.8858 \\
3 & 48.43 & 1.3 & 33.26 & 8.40 & 17.50041 \\
4 & 87.18 & 1.3 & 60.06 & 15.18 & 19.29834 \\
\hline
\end{tabular}

\section{Statistical results}

Table 08 shows the results of the variance of the interactions between the reagents obtained from the statistical package used, from which the significance of each interaction is evaluated:

Table 8: Variance Chart

\begin{tabular}{|c|c|c|c|}
\hline Description & F-Value & P-Value & $\begin{array}{c}\text { Interactions } \\
(\alpha=0.05)\end{array}$ \\
\hline $\mathrm{H}_{2} \mathrm{SO}_{4}$ & 257.7 & 0.004 & $\begin{array}{l}\text { P-Value }<\alpha \\
\text { Significativo }\end{array}$ \\
\hline $\mathrm{NaCl}$ & 71.86 & 0.014 & $\begin{array}{l}\text { P-Value }<\alpha \\
\text { Significativo }\end{array}$ \\
\hline $\mathrm{KNO}_{3}$ & 31.71 & 0.03 & $\begin{array}{l}\text { P-Value }<\alpha \\
\text { Significativo }\end{array}$ \\
\hline $\mathrm{H}_{2} \mathrm{SO}_{4}{ }^{*} \mathrm{NaCl}$ & 0.18 & 0.71 & $\begin{array}{c}\text { P-Value }>a \\
\text { No Significativo }\end{array}$ \\
\hline $\mathrm{H}_{2} \mathrm{SO}_{4}{ }^{*} \mathrm{KNO}_{3}$ & 8.34 & 0.102 & $\begin{array}{c}\text { P-Value }>a \\
\text { Poco Significativo }\end{array}$ \\
\hline $\mathrm{NaCl}^{*} \mathrm{KNO}_{3}$ & 5.44 & 0.145 & $\begin{array}{c}\text { P-Value }>a \\
\text { Poco Significativo }\end{array}$ \\
\hline $\mathrm{H}_{2} \mathrm{SO}_{4}{ }^{*} \mathrm{NaCl}^{*} \mathrm{KNO}_{3}$ & 1.04 & 0.416 & $\begin{array}{c}\text { P-Value }>a \\
\text { No Significativo }\end{array}$ \\
\hline Curvatura & 0 & 0.978 & $\begin{array}{c}\text { P-Value }>a \\
\text { No Significativo }\end{array}$ \\
\hline Error & 0.3528 & 0.1764 & \\
\hline
\end{tabular}


Under the evaluation conditions, the result of the value of $\mathrm{R} 2=99.47 \%$ and the average error of 0.42 for the experimentation performed which is $97.35 \%$. To observe and evaluate the presence of curvature in the mathematical model (Gàlvez Edelmira, 2011), and the significance of the reagents, Fig. 5 is presented.

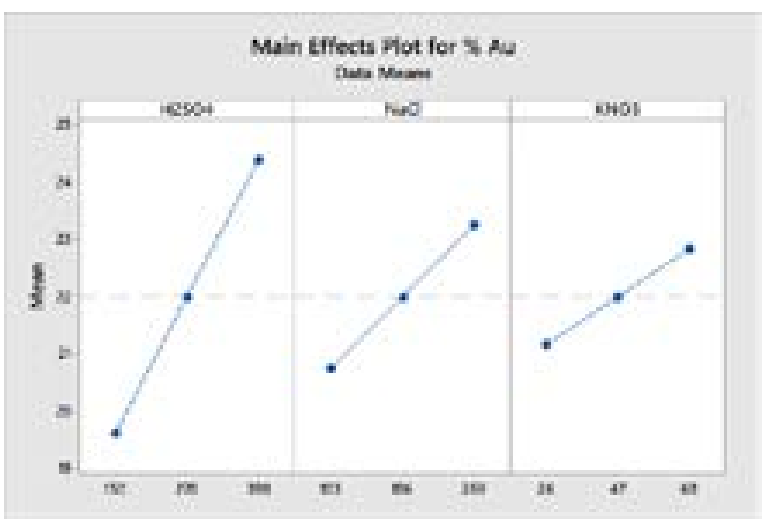

Fig. 5: Independent variables in the recovery of Au.

Fig. 6 of Pareto, shows the effect of reactants on the percentage of recovery of $\mathrm{Au}$

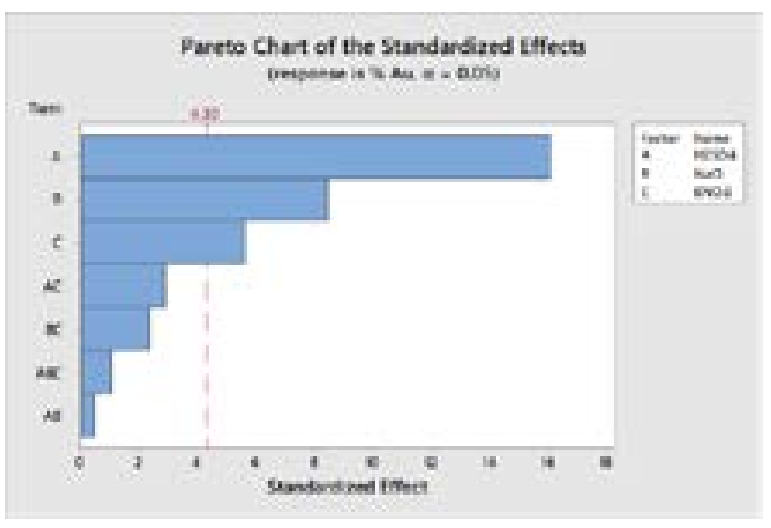

Fig. 6: Standardized\% Au dissolved in leaching with oxidizing salts in acidic medium.

In Fig. 7, the contour of the response surface is observed, which indicates that the maximum recovery of dissolved gold is $>26 \%$, (according to experimental results it is $26.62 \%$ ), the dark green color indicates the area of greater influence.

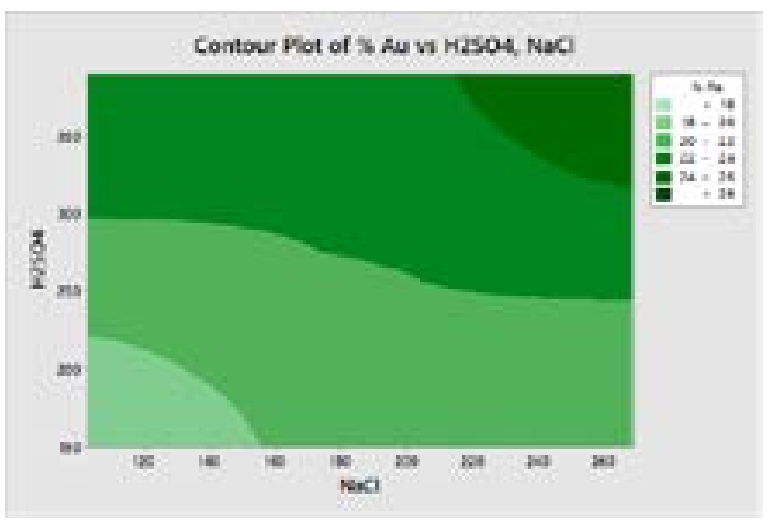

Fig. 7: $\mathrm{NaCl}$ Estimated response surface contour, $\% \mathrm{Au}$ vs $\mathrm{H} 2 \mathrm{SO} 4, \mathrm{NaCl}$.
Fig. 8 is presented, which establishes the contour of the response surface, and the recovery behavior of Au by taking 5 new concentrations for each reagent. The maximum recovery of the dissolved $\mathrm{Au}$ greater than $29 \% \mathrm{Au}$ is shown, the dark green color being located.

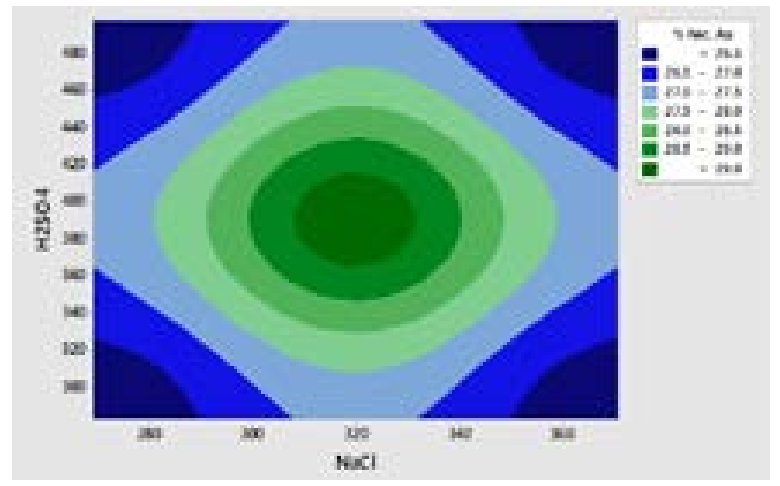

Fig. 8: Contour of the complementary experimentation, \% Au vs $\mathrm{H} 2 \mathrm{SO} 4, \mathrm{NaCl}$.

\section{DISCUSSION}

The greatest recovery of gold as a function of time occurs at 8 hours, these results are related to other studies (Alfaro Lopez, 2014) (Ñaupa, 2012), to obtain a maximum recovery, the leaching time is set between 10 - 13 hours for a $20 \%$ recovery, differing slightly from the results obtained (Beltran Aguilar, 2006); an explanation is found for the mineralogical composition that the mineral presents. Comparing the recovery trend found after 8 hours, with the results obtained by the bibliographic studies, a slight decrease in recovery is shown, and a variation that is explained based on the "Preg - robbing" Effect, where the dissolved gold "Recovered" is adsorbed by the different types of clays present in the mineral, establishing similar study conditions (Visurraga Reinoso, 2007); With results that adsorbed gold goes from $0.38 \%$ to $1.4 \%$, this is not noticeably visible, so it must be a reversible "Preg - robbing" effect, this problem can be reversed in the presence of activated carbon.

For the greater recoveries of gold at different concentrations of $\mathrm{H} 2 \mathrm{SO} 4, \mathrm{NaCl}, \mathrm{KNO} 3$, it tends to increase with the variation of the concentrations, which shows its importance as each concentration varies, this is also related to the studies, influencing the oxidizing salts and the medium acid with respect to other variables such as temperature, time and the percentage of solids.

The maximum recovery of gold is $26.62 \%$, this recovery does not exceed $27 \%$ compared to the recovery in a traditional cyanidation process, the cause of the low recovery of gold is established by the complex composition of the mineral, presence of interfering: coarse gold, electrum, and clays, being related to the studies (Beltran Aguilar, 2006), who achieve a recovery of no more than $20 \%$, concluding that the main cause is the passivation and presence of the mineral Jarosita, who causes interference in the process by encapsulating the valuable mineral.

For statistical results, the interactions of the reagents and the curvature in the mathematical model are observed, the interactions between the three variables of $\mathrm{H} 2 \mathrm{SO} 4, \mathrm{NaCl}$, $\mathrm{KNO} 3$ and the curvature are greater than the value of $\alpha=0.05$, meaning that their variation does not influence significantly 
in the response variable and therefore are not significant for the mathematical model (Gàlvez Edelmira, 2011), finding a first-order model, whose trend of curve, determines the nonlinearization with the trace of the trend of concentrations from high, Medium to low.

For Pareto's observations with 4.30 as a limit of significance according to the regression equation, the concentration of $\mathrm{H} 2 \mathrm{SO} 4$ is more significant than the salts and the combination between them, where it is corroborated that the greatest recovery is directed towards the higher concentration of sulfuric acid, deferring what it indicates (Naupa, 2012) in the process is in the interactions of sodium chloride and potassium nitrate.

From the contrast between the phenomenological model (Gálvez, 2012) and the statistical model, the phenomenological model presents a prediction closer to the reality "experimental recovery of gold XAu" compared to the statistical model, because the determination of this phenomenological model It is based on the chemical kinetics of the process under study (Seiko, y otros, 2017), where the concentration of the reagents was evaluated in a fractional time, a first order reaction was not assumed and it was taken as a controlling stage of the process of diffusion of the leaching reagent through the reaction surface.

\section{CONCLUSIONS}

It is concluded that leaching in acid medium with oxidizing salts for the ore under study is mainly affected by the presence of coarse gold, quartz and electrum associated with clays, since the maximum recovery of gold obtained was $29.31 \%$, where concentrations of the reagents were determined experimentally. To improve the recovery of gold from $26.62 \%$ to $29.31 \%$, the concentration of $\mathrm{NaCl}$ should be increased to $103.33 \mathrm{~g} / 1$, the concentration of KNO3 should be increased to $25.42 \mathrm{~g} / 1$ and the concentration of $\mathrm{H} 2 \mathrm{SO} 4$ should be maintained at $125.93 \mathrm{~g} / 1$, observing the influence of recovery respectively. Another aspect to take into account is that the presence of clays establishes passivation effects, sequestration of the Au already dissolved, significantly influencing the recovery, producing a slight decrease as the leaching time increases. This is shown in the models that predict the behavior of the process with greater accuracy and precision, this model is the phenomenological model, based on the leaching kinetics, whose dissolution of the process in acidic medium is faster than the kinetics of the traditional process of cyanidation, whose leaching time is set at approximately $72 \mathrm{hrs}$, compared to the 8 hours it takes to leach in an acid medium with oxidizing salts. Direct leaching is established in an acid medium that is not convenient, due to the interference mainly of thick $\mathrm{Au}$, to be able to separate the mineral from said interference, the important one being the application of a pretreatment.

\section{ACKNOWLEDGMENT}

Thanks are extended to the Institute for Research and Innovation in Renewable Energies and the Environment of the Catholic University of Santa María for the support in research.

\section{REFERENCES}

1. Alfaro Lopez, C. A. (2014). Influencia de la variación de las concentraciones de Ácido Sulfúrico Nitrato de Sodio y Cloruro de Sodio en la Extracción de Oro de Minerales Oxidados mediante el Proceso Severo. 4-73: Universidad Nacional de Trujillo.

2. Alvarez Q, ,. A. (2006). Tecnología de la Concentración Centrífuga. Universidada Mayor de San Andres, 1-90.

3. Apablaza, A., Díaz, D., Rodríguez, E., \& Vera, S. (s.f.). Estudio Cinético de lixiviación de Oro. Universidad Técnica Federico Santa María Valparaíso, 1-6.

4. Asamoah, R. K.-M. (2018). Alkaline cyanide leaching of refractory gold flotation concentrates and biooxidised products The effect of process variables. Hydrometallurgy, 79-93.

5. Beltran Aguilar, A. (2006). Lixiviación del mineral aurífero con sales oxidantes en medio ácido. Bucaramanga: Universidad Industril de Santander.

6. Bustamante R, O. (1992). Concentración de minerales - Programa Modular de Minerales Auro-Argentíferos. SENA - Universidad Nacional Mineralógico.

7. Cornejo, H. G. (Diciembre de 2010). Tratado de Pirometalurgia. Arequipa.

8. Domic, E. (2001). Hidrometalurgia: fundamentos, procesos y aplicaciones. Santiago de Chile: Andros Impresores.

9. Edelmira D Gálvez, L. M. (2012). Heap leaching of caliche minerals Phenomenological and analytical models Some comparisons. Minerals Engineering, 46-53.

10. Evelien Martens, H. Z. (2012). In situ recovery of gold: Column leaching experiments and reactive transport modeling. 16-23: Hydrometallurgy.

11. Gallardo, J. V. (1980). Metalurgia del Oro y la Plata. Lima: San marcos.

12. Gálvez, E. D. (2012). Heap leaching of caliche minerals: Phenomenological and analytical models. Minerals Engineering, 46-53.

13. Gàlvez, E., Moreno, L., Mellado, M., Ordòñez, J., \& Cistemas, L. (9 de December de 2011). Heap Leaching of caliche minerals: Phenomenological and analytical models. Elsevier, págs. 47-53.

14. Jorge, G. E. (2012). Evaluación del proceso de lixiviación por agitación de minerales de $\mathrm{Au}-\mathrm{Ag}$ en la compañía minera Ares. Cusco.

15. Lovera D., D., Coronado F., R., Aramburu, S., Quiñones, J., \& Puente, L. (2003). Modelaiento matemàtico en los procesos de lixiviaciòn de minerales aurìferos y cuprìferos en sistemas quìmicos. Instituto de investigaciones de la facultad de Geologìa, Minas, Metalurgia y Ciencias Geogràficas, 64-70.

16. Martens Evelien, Z. H. (2012). In situ recovery of gold: Column leaching experiments and reactive transport modeling. Hydrometallurgy, 16-23.

17. Martens, E. Z. (2 de May de 2012). In situ recovery of gold: Column leaching experiments and reactive transport modeling. Hydrometallurgy, 125-126, 16-23.

18. Meissl, R. J., Quizano, V. A., García, H., \& Barrera, E. M. (2011). Determinación de Preg - Robbing en muestras auríferas del noroeste de la provincia de San Juan, Argentina. Instituto de Investigaciones Mineras y Departamento de Ingeniería de Minas, Universidad 
Nacional de San Juan, Argentina, 42-46.

19. Mellado, M. C. (2009). An analytical approach to heap leaching. 33-38: Hydrometallurgy.

20. MEN. (2017). Dirección de General de Minería. LimaPeru: Ministerio Energias y Minas.

21. Misari Chuquipoma, F. S. (2010). Metalurgia del Oro. Lima: San Marcos E.I.R.L.

22. Naupa, P. (2012). Lixiviación de minerales auríferos de vetas Daysi con sales oxidantes en medio ácido. Arequipa.

23. Palacios, S. (2001). Proceso Severo: Lixiviación de menas auríferas con sales oxidante en medio ácido. Lima: Consultor EDELMIN.

24. Palacios, S. (Enero - Junio de 2002). Lixiviación de menas auríferas con sales oxidantes en medio ácido. Lima: Minas Metalurgia y Ciencias Geográficas.

25. Seiko, S., Lampinen, M., Jari, A., Laari, A., Koiranen, T., \& Lundstrum, M. (18 de October de 2017). Kinetics and mechanisms of gold dissolution by ferric chloride leaching. Elsevier, págs. 132-141.

26. Severo, P. (1993). Ingeniería de lixiviación. Tacna: CONCYTEC.

27. Sipi Seisko, M. L. (2018). Kinetics and mechanisms of gold dissolution by ferric chloride leaching. Minerals Engineering, 131-141.

28. SNMPE, S. N. (01 de Enero de 2018). Boletín estadístico mensual minería. Obtenido de SNMPE: http://www.snmpe.org.pe/mineria.html

29. Taipe Ch., J. (2015). Manual de Procedimientos de Laboratorio Químico Metalúrgico. Ayacucho: Minera Laytarurma.

30. Valencia, J. M. (2008). Saltpeter extraction and modelling of caliche mineral heap leaching. 103-114: Hydrometallurgy .

31. Visurraga Reinoso, R. A. (2007). Efecto de las arcillas en la cianuración de oro en pilas o montones. Lima: Ingeniero Metalurgista. 